DOI: $10.19195 / 2353-8546.4 .7$

MAJA HARBUZIUK ${ }^{*}$

Narodowy Uniwersytet im. Iwana Franki we Lwowie (Ukraina)

\title{
Współczesny teatr ukraiński: między dyskursem posttotalitarnym a postkolonialnym
}

Ukrainian modern theatre: Between post-totalitarian and post-colonial discourse. The attempt to divide into periods the activity of Ukrainian theatre in the era of Independence is made. The main features of these periods are revealed and the regional differences indicated. Attention is paid to the influence of crisis phenomena in social and political life of the post-totalitarian and post-colonial society on the development of theatrical art. Constructive changes in the progress of Ukrainian stage in the period of 1986-1991 are underlined, for example: lifting the censorship, opening acces to forbidden national anti-totalitarian and anti-colonial drama and others. The emphasis is put on the problems of the loss of continuity of generations of directors, reduction of positive phenomena, artificial creation of Ukrainian culture, the complex of "being secondary" in the next period. Manifestations of a new, in both form and meaning, theatre are related to the emergence of a new generation of directors and playwrights that began to explore the themes of contemporary private life and modern forms of dramatic writing.

Keywords: Ukrainian theatre of the Independence era, young Ukrainian art direction, young Ukrainian drama

Український сучасний театр: між посттоталітарним та постколоніальним дискурсами. Історію українського театру періоду Незалежності можна поділити на три періоди. Перший - це злам 1980-1990-х років, коли було скасовано цензуру і відкрито доступ до заборонених раніше п’єс репресованих тоталітарною системою авторів, а також до всього корпусу західноєвропейської, насамперед

* Adres do korespondencji: Факультет культури і мистецтв Львівського національного університету ім. І. Франка, вул. Валова, 18, 79007 Львів. E-mail: harbuzyuk.maya16@gmail.com. 
екзистенціальної, драматургії. Також в цей час виникло понад сто пошукових театрівстудій завдяки чому інтенсифікувався процес деконструкції ментальних стереотипів доби соцреалізму. Однак наступні двадцять років трансформації України, позначені поглибленням кризи у політичному, суспільному та економічному житті країни, призвели до сповільнення та зупинки тенденцій поступу, притаманних першим рокам Незалежності. Тому можна сказати, що в останні роки XX-перше десятиліття XXI століття театр живився інерцією попереднього вибуху зламу 1980-1990-х років, обравши стратегії самозбереження: як через естетизацію та інтелектуалізацію, так і через комерціалізацію театру. Цей період - на відміну від попереднього - дав невелику кількість нових цікавих постатей режисерів та драматургів. У свою чергу останні 5-6 років стали часом розвитку нових творчих тенденцій та явищ, коли театр дедалі частіше центром своєї уваги обирає приватну людину та їі мікросвіт. Це пов’язано, зокрема, із появою нового покоління митців (тридцятилітніх-сорокалітніх, тобто народжених або сформованих у Незалежній Україні), котрі надзвичайно послідовно прагнуть відкривати нову для української сцени проблематику: суспільства доби постколоніального та посттоталітарного переходу.

Ключові слова: український театру доби Незалежності, молода українська режисура, молода українська драма

We współczesnym ukraińskim teatroznawstwie nie omówiono jeszcze w sposób gruntowny i kompleksowy ostatnich trzydziestu lat działalności teatru narodowego. Wydaje się, że dopiero rewolucyjne wydarzenia Euromajdanu sprowokowały dyskusje na wiele tematów i problemów, które w dobie niezależności nie wybrzmiały wystarczająco dobrze lub wcale. Tak też się stało z ukraińskim teatroznawstwem, które nie zdołało się uporać ani ze spuscizną realnego socjalizmu, ani z szokiem zmiany systemowej po rozpadzie Związku Radzieckiego. Dlatego też tezy zawarte w prezentowanym tekście to próba mojego własnego syntetycznego spojrzenia na istniejące w teatrze ukraińskim po 1991 roku tendencje, procesy i zjawiska, odczytane w kontekście optyki posttotalitarno-postkolonialnej. Wszystkich zainteresowanych pojedynczymi, najważniejszymi spektaklami tego okresu odsyłam do takich monografii, jak: Teatr ukrainski XX wieku (Український театр ХX століття) Neli Kornijenko ${ }^{1}$, analitycznych opracowań Instytutu Sztuki Współczesnej Narodowej Akademii Nauk Ukrainy Szkice z historii ukraińskiej sztuki teatralnej XX wieku (Hapucu з історії театрального мистецтва України XX cm. $)^{2}$, niezwykle ważnego dodatku do tych opracowań, zatytułowanego Najnowszy ukraiński teatr dramatyczny (koniec XX-początek XX wieku) (Драматичний театр України новітньої доби [кінець XX-початок XXI cm.]) Anny Łypkiwskiej ${ }^{3}$, a także pracy zbiorowej Teatr ukraiński XX wieku. Antologia przedstawień (Український театр XX століття.

${ }^{1}$ Н. Корнієнко, Украӥнський театр ХХ століття, Київ 2003.

${ }^{2}$ Нариси з історії театрального мистеитва України ХХ ст., ред. В. Сидоренко, Київ 2006.

3 А. Липківська, Драматичний театр Украйни новітньої доби (кінецьь XX-початок XXI cm.), Київ 2011.

Miscellanea Posttotalitariana Wratislaviensia 4/2016

(C) for this edition by CNS 
Антологія вистав) ${ }^{4}$ oraz periodyków teatralnych, między innymi czasopism „Український театр”, „Кіно. Театр”, „Просценіум”.

Uważam, że współczesny okres funkcjonowania ukraińskiego teatru można, w sposób najogólniejszy, podzielić na trzy główne części. Pierwsza z nich przypada na koniec lat osiemdziesiątych i początek dziewięćdziesiątych, druga trwa od połowy lat dziewięćdziesiątych do końca pierwszego dziesięciolecia XXI wieku, natomiast trzecia rozpoczęła się na przełomie pierwszego i drugiego dziesięciolecia naszego stulecia i trwa. Jak widać, periodyzacja ta wynika bezpośrednio z tych procesów, które zachodziły w życiu społeczno-politycznym Ukrainy i jednocześnie jest ich odzwierciedleniem.

Współczesny model ukraińskiego teatru sformułowany został na przełomie lat osiemdziesiątych i dziewięćdziesiątych XX stulecia w warunkach tak zwanej przebudowy. Był to okres przejścia od totalitarnego do posttotalitarnego społeczeństwa, będący jednocześnie początkiem rozpadu imperium Związku Radzieckiego. Te dwa paradygmaty - posttotalitarny i postkolonialny — naznaczyły kolejne 25 lat ukraińskiej niezależności w sferze politycznej, narodowej, socjalnej i kulturalnej, pozostawiając swój ślad również w życiu artystycznym, w tym i teatralnym.

$\mathrm{Z}$ dzisiejszej perspektywy wyraźnie widać, że ukraiński teatr narodowy osiągnął szerokie ramy ideowej, estetycznej i organizacyjnej wolności jeszcze przed ogłoszeniem państwowej niezależności Ukrainy. Pluralizm ideowy był możliwy przede wszystkim dzięki zniesieniu cenzury. Wynikła wówczas potrzeba i zarazem możliwość odnowienia pamięci historycznej dzięki inscenizacjom dzieł dotąd zakazanych (w przeważającej mierze dotyczyło to dramaturgii modernistycznej, między innymi Łesi Ukrainki, Bohdana Łepkiego, Ołeksandra Ołesia, Wołodymyra Wynnyczenki) oraz autorów tak zwanego rozstrzelanego odrodzenia (Mykoły Kulisza, Mykoły Chwylowego, Kostia Burewija etc.) czy też twórców pokolenia lat sześćdziesiątych XX wieku, nazywanego też często uduszonym odrodzeniem (Wasyla Symonenki, Liny Kostenko etc.). Powstała również potrzeba opanowania (nowego dla ukraińskiego teatru) teatru umownego, a także dramaturgii teatru egzystencjalnego (Jean-Paul Sartre, Albert Camus, Tadeusz Różewicz, Sławomir Mrożek), jak również utworów Friedricha Dürrenmatta, Edwarda Albeego. Swoją rolę odegrał również późnoradziecki, właściwie stojący na pograniczu doby postsowieckiej, repertuar rosyjskich lub rosyjskojęzycznych twórców. Mam tu na myśli takie dzieła, jak: Pokuta (Плаха) Czyngiza Ajtmatowa, Dzieci Arbatu (Діти Apбama) Anatolija Rybakowa, sztuki sceniczne Ludmiły Pietruszewskiej, Niny Sadur, Ołeksandra Galina i in. W utworach tych zawarto krytykę radzieckiej rzeczywistości, a także odważnie podejmowano przemilczane dotąd tematy narkomanii, prostytucji czy alkoholizmu.

Teatr ukraiński tego okresu był niezwykle różnorodny pod względem ideowym. Przede wszystkim uosabiał nadzwyczaj aktywną postawę obywatelską:

4 Український театр ХХ століття. Антологія вистав, ред. М. Гринишина, Київ 2012. 
antytotalitarną i antykolonialną, mocno uwypuklając przy tym problemy o charakterze narodowym, politycznym i socjalnym. Teatry znajdujące się na zachodzie Ukrainy łączyły krytykę sowieckiej rzeczywistości z antykolonializmem, antyimperializmem i nacechowaniem antyrosyjskim. W ten sposób dyrektor artystyczny Lwowskiego Teatru Akademickiego im. Marii Zańkowieckiej, Fedir Strygun, wystawiając sztukę Ludowy Malachiasz (Народний Малахіŭ) Mykoły Kulisza (1989), jednocześnie wprowadził do repertuaru spektakl Pawło Połubotek (Павло Полуботок) Kostia Burewija (1990) oraz trylogię Iwana Łepkiego Mazера (Мазеna) w inscenizacji Bogdana Antkowa (1991-1992). Natomiast teatry we wschodnich regionach zwracały się raczej ku antykomunistycznej i antysowieckiej tematyce. Reżyser Ihor Bielacki w Charkowskim Teatrze Akademickim im. T. Szewczenki (dawny Teatr Berezil Kurbasa), doprowadził do wystawienia komedii Myna Mazajło (Мина Мазайло) Kulisza, co stało się kultowym wydarzeniem w życiu teatralnym na Ukrainie, wywołując ogromny rezonans w całym kraju. Spektakl był gościnnie pokazywany widowni także w innych miastach kraju. Główna scena Ukrainy, Kijowski Teatr Akademicki im. I. Franki, przede wszystkim w osobie dyrektora artystycznego Sergija Danczenki, jeżeli chodzi o zmiany ideowe, reagowała umiarkowanie. Jednak nie mniej wyraźnie niż w innych teatrach zwracano się tutaj do uniwersalnych wartości ogólnoludzkich, przede wszystkim w inscenizacji Tewje Tewel (Тев'є-Тевль) Grihorija Gorina (1989) według Szolema Alejchema z Bogdanem Stupką w roli głównej.

W nowych, sprzyjających warunkach ukształtował się całkiem nowy dla ojczystego teatru obszar, to jest obszar teatru z zasady asocjalnego, teatru socjalnego przemęczenia, teatru prywatności. Teatr ten dotarł na Ukrainę wraz z absolwentami „szkoły” Anatolija Wasiljewa i reprezentował różne oblicza jednej historii: skrajnego indywidualizmu, sceptycyzmu, upadku wartości i wyczerpania energii witalnej, czego następstwem było wyodrębnienie terytorium sztuki z przestrzeni życia. W tym sensie sztuka stała się ratunkiem dla artysty, co podkreślano świadomą sakralizacją i etapami wtajemniczenia w działalność różnych ośrodków. Potrzeba nowego spojrzenia na teatr, społeczeństwo i jednostkę przejawiła się w niezwykłym zainteresowaniu przedstawieniami, które stały się kultowe dla swojego czasu. Były to: Archeologia (Археологiя) Ołeksego Szypenki w reżyserii Walerija Bilczenki (Mołodyj Teatr, 1989), Мoment (Момент) według Wołodymyra Wynnyczenki w reżyserii Andrija Żołdaka (Scena Kameralna Kijowskiego Teatru im. I. Franki, 1988), a także przedstawienia Klubu Teatralnego w reżyserii Ołega Lipcyna, jak również pierwsze prace Lwowskiego Teatru im. Łesia Kurbasa pod kierownictwem Wołodymyra Kuczyńskiego (od 1988). Wytrawna badaczka tego okresu, znana ukraińska teatroznawczyni Anna Łypkiwska, pisze:

Nadzwyczajność, jak i zresztą nowość takiego teatru polegała na jego otwartej opozycyjności wobec zastanych form teatru i życia, wobec spojrzenia na teatr jak na instytucję społecznie, 
ideologicznie bądź w jakikolwiek inny sposób zaangażowaną [...] Można to było uważać za naturalną reakcję na wieloletnie panowanie reguł totalitarnych we wszystkich sferach życia ${ }^{5}$.

W tym czasie teatr zasilił, razem z wychowankami „szkoły Wasiljewa”, szeregi reżyserów. Cytowana powyżej Łypkiwska wymienia ponad dwadzieścia nazwisk, wśród których znajdują się wychowankowie znanego reżysera, dyrektora artystycznego Kijowskiego Akademickiego Teatru Dramatu i Komedii na lewym brzegu Dniepru, Edwarda Mytnickiego (Dmytro Bohomazow, Jurij Odynoki, Ołeksa Lisowec). Są to także takie postacie, jak Atyłła Wydniański, Sergij Proskurnia, Stepan Pasicznyk, Ołeksa Krawczuk, Andrij Prychod'ko, Wołodymyr Petrenko i in. Ani wcześniej, ani później nie było na Ukrainie tak licznego i reprezentującego tak wysoki poziom artystyczny cechu reżyserskiego. Ludzie ci reprezentowali różne szkoły i światopoglądy, odmienne wyobrażenia na temat sztuki teatralnej, ale przede wszystkim byli oddani teatrowi autorskiemu, teatrowi indywidualnego z zasady światopoglądu, teatrowi stworzonemu przez reżysera-demiurga. Jak pisze na ten temat Anna Łypkiwska,

[R]eprezentowany przez nich model teatru reżyserskiego stał się charakterystycznym zjawiskiem epoki rozpadu wszystkiego, od codzienności po idee, epoki krachu prostolinijnych wyobrażeń o otaczającej rzeczywistości (przede wszystkim społecznej), epoki upadku autorytetów i przełamywania stereotypów, epoki, która usunęła spod nóg stabilny grunt: przeszłość jawiła się jako nieznana, przyszłość problematyczna, a teraźniejszość jako bezwartościowa ${ }^{6}$.

Jeszcze jedną cechą charakterystyczną tego barwnego, wpływowego pokolenia było to, iż przeważająca większość spośród wymienionych reżyserów to prawdziwi liderzy, którzy skupiali wokół siebie podobnie myślących aktorów, tworząc niewielkie teatry. Od końca lat osiemdziesiątych do końca dziewięćdziesiątych założono wiele nowych ukraińskich teatrów studyjnych. To przede wszystkim teatry kijowskie: Teatr na Podolu „Коło” (Театр на Подолі „Колесо”), Centrum Współczesnej Sztuki Teatralnej „DACH” (Центр Сучасного Мистецтва „ДАХ”), lwowskie: Teatr im. Łesia Kurbasa (Львівський академічний театр імені Леся Курбаса), Zmartwychwstanie (Воскресіння), W Koszyku (У кошику), charkowskie: P.S., Arabeski, dniepropietrowski Wierzymy! (Віримо!) i in. (podaję tylko te, które działają do dziś).

$\mathrm{W}$ połowie lat dziewięćdziesiątych, na fali euforii pierwszych lat niepodległości, przyszłość ukraińskiego teatru jawiła się jako urozmaicona i pełna perspektyw. Zaczęto organizować pierwsze festiwale teatralne, otwierano nowe szkoły teatralne. Współczesna ukraińska dramaturgia również dała o sobie znać, chociaż nie było na nią szczególnego popytu ze strony teatrów: nadal odkrywano dotąd zakazane przez radziecką ideologię nazwiska i utwory, co sprawiało wrażenie zapełnienia repertuaru.

${ }^{5}$ А. Липківська, Молодий театр України кіния 80-х-початку 90-х років: посмодерна ідеологема свідомсті та ї відбиток у сиенічному артефакті, Записки НТШ. Праці Театрознавчої секції, Львів 1999, т. 137, s. 355-357.

${ }^{6}$ Ibidem, s. 346. 
Jednak realia dopiero co odzyskanej państwowości i niepodległości w istocie okazały się niezbyt radosne i optymistyczne. Po okresie euforii, już w połowie lat dziewięćdziesiątych, nastał czas kryzysu świadomości znacznej części ukraińskiego społeczeństwa, który w następnych latach znacząco się pogłębiał. Brak jednoznacznej państwowej polityki kulturalnej w połączeniu z kryzysem ekonomicznym doprowadził teatr do funkcjonowania na skraju bankructwa, odsuwając jednocześnie na drugi plan kwestię ideowości, opozycyjności wobec oficjalnej władzy oraz intensywności dialogu ze społeczeństwem. $Z$ przyczyn finansowo-organizacyjnych przestał działać Klub Teatralny oraz znaczna część niewielkich teatrów studyjnych, a z Ukrainy wyjechali między innymi Waleryj Bilczenko, Andrij Kritenko, Ołeg Lipcyn. Te teatry, które nadal działały, mogły się uratować tylko poprzez instytucjonalizację. W ten sposób status teatru państwowego, otrzymując jednocześnie status akademicki, uzyskały wspomniane już Teatr im. Łesia Kurbasa, Воскресіння сzy Teatr na Podolu.

Jak wiadomo, mechanizmy społeczeństwa posttotalitarnego, działając wciąż jeszcze według zasad ukształtowanych $\mathrm{w}$ dobie realnego socjalizmu, dawały złudzenie twórczej wolności: w warunkach nomenklaturowego kierownictwa obowiązywał system podziału dóbr socjalnych wśród artystów (statusy, tytuły etc.), raziły również ograniczenia i nieprzejrzystość zasad finansowania. Państwowy teatr w znacznej mierze przekształcił się w jeszcze jedną skorumpowaną krajową instytucję, będąc na swój sposób państwem w miniaturze. Jedyna różnica polegała na tym, iż inaczej niż w minionej epoce, teatr nie musiał już być trybuną dla głosu władzy. Był jej po prostu niepotrzebny. Niestety, nie był on też w jakiś szczególny sposób potrzebny widzowi, bo analiza problemów jednostki - czy to w wymiarze społecznym, czy prywatnym - była w ogóle wyniesiona poza ramy funkcjonowania społecznych praktyk. Znana krytyk i historyk teatru Natalia Jermakowa, oceniając tę sytuację, w 2001 roku z goryczą pisała:

Niestety, przyjdzie po raz kolejny odnotować: na współczesnej scenie narodowej zupełnie nie ma człowieka współczesnego. Oznacza to, że widzowie nie mają się z kim identyfikować. Współczesny Ukrainiec to kategoria teatralnie zupełnie nieznana ${ }^{7}$.

Pojawienie się zbiorów dramatów W oczekiwaniu na teatr. Antologia młodej dramaturgii (У чеканні театру: Антологія молодої драматургіï, Kijów 1998), Strajk iluzji. Antologia wspótczesnej ukraińskiej dramaturgii (Страйк ілюзій: Антологіï сучасної української драматургіï, Kijów 2004) сzy publikacja almanachu Wspótczesna ukraińska dramaturgia (Сучасна украӥнська драматургія, Kijów 2005, 2006) nie wpłynęło w sposób istotny na poprawę sytuacji, albowiem „pogłębienie się przepaści między teatrem a dramaturgią, zaostrzonej problemami w samej dra-

${ }^{7}$ Н. Єрмакова, Вітчизняна молода режисура: перетин двох тисячоліть, „Просценіум” 2001, ч. 1, s. 50. 
maturgii, przede wszystkim jej nieadekwatność wobec zasad sceny, potrzeb teatru i widza" było oczywiste ${ }^{8}$.

Ukraiński teatr coraz bardziej odchodził na wewnętrzną emigrację. Dla jednych było to pogłębienie kontemplacji kwestii światopoglądowych, estetycznych czy artystycznych, opartych na dziełach światowej i narodowej klasyki, a dla innych była to próba przeżycia na rachunek kasowego repertuaru. Przy całkiem zrozumiałej dla posttotalitarnego społeczeństwa praktyce centralizacji życia teatralnego, robiono wszystko, co możliwe, aby nie dopuścić do wyrównania teatralnego krajobrazu pomiędzy stolicą a prowincją, podtrzymując ideologiczną wtórność kulturalnych peryferii wobec stołecznej sztuki. W okresie oficjalnego wsparcia teatru tak naprawdę uczyniono wszystko, aby ideę prowincjonalności zachować żywą, nie tylko na terenie krajowym, lecz także w szerszym, międzynarodowym kontekście. Sprzyjała temu sztuczna hermetyzacja ukraińskiej kultury teatralnej. Artyści, a przede wszystkim młodzi reżyserzy, dramaturdzy, aktorzy, teatroznawcy, „dusili się we własnym sosie", nie mając możliwości bezpośredniego i swobodnego dostępu do współczesnego światowego czy europejskiego doświadczenia teatralnego. O ile w latach dziewięćdziesiątych swoistymi oknami na ten świat były festiwale Złoty Lew, Tarnopolskie Wieczory Teatralne, Artystyczne Berezill’a i in., o tyle już na początku XXI stulecia jeden po drugim kończyły one swoją działalność. W kontekście teatru ukraińskojęzycznego można było mówić o stworzeniu pewnego rodzaju getta ukraińskiej kultury: między granicą z Polską na zachodzie, a rzeką Dniepr na Wschodzie. Tak jakby mur berliński nie upadł, lecz przesunął się na Wschód, na granicę Unii Europejskiej z Ukrainą. Patrząc na kwestię wzajemnych oddziaływań, strefa kontaktów teatralnych na wschodzie Ukrainy praktycznie pozostawała nieograniczona, a teatr rosyjskojęzyczny podtrzymywał i kontynuował kolonialną politykę, której tragiczne skutki można dzisiaj obserwować.

Jednak mimo ogólnego kryzysu artystycznego, będącego częścią kryzysu społecznego, ukraiński teatr nawet w najmniej sprzyjającym okresie zdobywał się na znaczące czyny. Od czasu do czasu przedstawiał diagnozę kondycji społeczeństwa czy sygnalizował największe społeczne bolączki, a nawet prognozował przyszłe trzęsienia.

Sygnały te istniały w przestrzeni dyskursu antykolonialnego i antytotalitarnego. Ostra krytyka reżimu komunistycznego wybrzmiała w przedstawieniach Żołdaka: Jeden dzień z życia Iwana Denisowicza (Один день Івана Денисовича według Aleksandra Sołżenicyna, Charkowski Teatr Akademicki im. T. Szewczenki, 2003), Lenin love, Stalin love (Ленін love, Сталін love według powieści Żólty kniaź [Жовтий князв] Wasyla Barki, 2008; w przedstawieniu brali udział aktorzy Czerkaskiego Akademickiego Teatru im. T. Szewczenki; było ono, pierwszy raz w historii ukraińskiego teatru, transmitowane na żywo na głównym kanale telewizyjnym), a także w spektaklu Zimna krew (Голодна кров Oleny Biłyk, Tetiany Wołkowej i Daryny Medwiedie-

${ }^{8}$ А. Липківська, op. cit., s. 26. 
wej, w reżyserii Wołodymyra Petrenki; Dniepropietrowski Teatr Biримo!; ostatnie dwa przedstawienia przygotowano z okazji rocznicy Wielkiego Głodu). Proza Marii Matios również stała się jedną ze składowych antyradzieckiego dyskursu, a na zachodzie Ukrainy zrealizowano kilka odczytów scenicznych jej utworów, z których najważniejsze to: Słodka Darusia i Nacja w reżyserii Rościsława Derżypilskiego w Iwano-Frankowskim Akademickim Teatrze im. I. Franki. Zarówno te, jak i stosunkowo niedawne premiery, jak np. Moskowiada Jurija Andruchowycza w reżyserii Stanisława Mojsejewa (2006), do dziś znajdują się w repertuarze Kijowskiego Teatru Młodego. Również w przedstawieniu Edyp. Buda dla psa (Edin. Собачa будка) KLIMa w Centrum Współczesnej Sztuki Teatralnej „DACH” w reżyserii Władysława Troickiego (2010) tematy agresji i zniewolenia jednostki przedstawione są niezwykle realistycznie i dosłownie.

Osobną kwestią w rozwoju zarówno antykolonialnego, jak i antytotalitarnego dyskursu stał się spektakl U.B.N. (Ukraiński Burżuazyjny Nacjonalista) /У.Б.H. (Український буржуазний наиіоналіст) Hałyny Telniuk, wystawiany na deskach Lwowskiego Teatru Narodowego im. M. Zańkowieckiej (2001). Przedstawienie to wywołało nadzwyczajny rezonans w wielu miastach Ukrainy, gdyż w sposób jednoznacznie krytyczny diagnozowało antyukraińskość i kompradorstwo urzędującej władzy oraz demaskowało totalitarną ideologię w retoryce tylko na pozór posttotalitarnego państwa. W innym przedstawieniu: Ostatni hreczkosiej (Останній гречкосій) Oresta Ohorodnyka (2011), aktorzy tego teatru bardzo dokładnie ukazali granice napięcia pomiędzy narodem ukraińskim a antynarodową władzą, otwarcie mówiąc o masowym zrywie sprzeciwu. Co ciekawe, obydwa spektakle - pierwszy powstał trzy lata przed pomarańczową rewolucją, drugi trzy lata przed rewolucją godności - mogły z niezwykłą dokładnością pokazać stopień społecznego napięcia obywatelskiego i przewidzieć masowy sprzeciw. Nie na darmo w rękach Zenona (aktor Fedir Stryhun) w finałowej scenie spektaklu U.B.N. pojawiła się siekiera, a bohater przedstawienia Ostatni hreczkosiej, mieszkaniec wsi Ohrim (aktor Janusz Juchnicki), w końcowym epizodzie szedł z widłami, aby zamordować posła (to dokonywane już za kulisami zabójstwo publiczność witała za każdym razem entuzjastycznymi oklaskami, przejawiając chęć stawienia oporu, tłumioną dotychczas wśród codziennego - tylko pozornie - spokojnego trybu życia).

W latach dziewięćdziesiątych XX wieku i w pierwszej dekadzie XXI ważną rolę $\mathrm{w}$ budowaniu pamięci zbiorowej widzów, przede wszystkim na zachodzie Ukrainy, odegrały również przedstawienia $\mathrm{z}$ repertuaru religijnego. To spektakle teatru Воскресіння, m.in. Hiob Karola Wojtyły (2005), a także Teatru im. Zańkowieckiej: misterium Jezus, Syn Boga Żywego (Ісус, Син бога Живого) Wasyla Bosowycza, według Ewangelii Nowego Testamentu (1994), Andrzej (Андрей) Wasyla Herasymczuka (2000). To właśnie teatr religijny, wertepy, obrzędy bożonarodzeniowe czy festiwal Bożonarodzeniowe Misterium (Різдвяна містерія) w Łucku - dyrektor festiwalu Danyło Posztaruk - pomogły w przywróceniu pamięci, która reanimowała duchową aurę znaczącej części narodowej wspólnoty. Jednak tematyka ta uległa 
w znacznej mierze wyczerpaniu i od połowy pierwszego dziesięciolecia XXI wieku zanikała.

Osobną traumą dla całej ukraińskiej kultury oraz ukraińskiego społeczeństwa — w tym również teatru — była całkowita utrata demokratycznych zdobyczy pomarańczowej rewolucji. Kryzys zaufania, niemoc i kryzys świadomości okazały się na tyle głębokie, że tak naprawdę nie mogły w sposób adekwatny przejawić się w przestrzeni publicznej, jaką jest sztuka teatralna. Pojedyncze przypadki (już wspomniany Ostatni hreczkosiej czy Edyp. Buda dla psa) tylko podkreślały tę ogólną tendencję.

Mimo to energia „wybuchu” pierwszych lat niezależności nie przepadła bez śladu i można ją było odnaleźć w twórczości pojedynczych reżyserów wielkich scen akademickich, a także w lokalnych punktach oporu, czyli niewielkich teatrach, zorientowanych przede wszystkim na intelektualnego, elitarnego widza. Niezwykle ważnymi, konstruktywnymi i konsolidującymi praktykami stały się ich poszukiwania estetyczne. Tworzenie narodowych matryc odbywało się przez konstruowanie neobarokowych, neorytualnych, neomisterialnych formuł. Chodzi tu o twórczość Lwowskiego Akademickiego Teatru im. Łesia Kurbasa, Centrum Sztuki Teatralnej „DACH” czy teatru P.S. W wielu przedstawieniach tych teatrów obecne było tworzenie narodowego kosmosu, powrót do archetypowych, dźwiękowych, wizualnych i zmysłowych kodów, do folkloru, autentyczności materialnej i duchowej - wszystko to sakralizowało narodowy mit i przywracało widzowi pradawną narodową świadomość kolektywną. Gdyby nie te i inne tego typu przedstawienia, gdyby nie narodowa misja ukraińskich teatrów, które istniały w totalnie rosyjskojęzycznym środowisku na wschodzie i południu Ukrainy (w Charkowie, Doniecku, Ługańsku, Mikołajowie, Odessie, Chersoniu), można by było mówić o całkowitej obojętności ukraińskiego teatru wobec życia współczesnej jednostki i wzajemnej utracie zaufania.

Pomijając działalność stalkerów, można by podsumować, że ukraiński teatr już od połowy XX wieku funkcjonował według zasad posttotalitarnego konformizmu, czyli cichego przystosowania się, przetrwania ekonomicznego, komercyjnego zysku lub estetycznego samozadowolenia. W społeczeństwie, w którym komunikowanie się poddane było kontroli lub odgórnie przerywane, teatr istniał, działał, miał lepszego bądź gorszego widza. Aczkolwiek odwiedzanie teatru stało się „takim sobie” kulturalnym rytuałem, tradycją lub daniną dla mody w środowisku nowych Ukraińców. W sytuacji podwójnej moralności, totalnej umowności, to wcale nie wydawało się dziwne. Dlatego też w tej sytuacji zupełnie naturalne było to, że ani doświadczenie współczesnej niemieckiej dramaturgii, której odczyty odbywały się regularnie na Ukrainie w pierwszej dekadzie XXI wieku, ani teksty polskich sztuk teatralnych, które również były znane, nie miały żadnego wpływu na ukraiński krajobraz teatralny. W istocie stanowił on zamkniętą strukturę, głuchą na głosy z zewnątrz, chociaż oficjalnie aktywną i zaangażowaną, również w działania międzynarodowe.

Właśnie w tym czasie doszło do krytycznego rozłamu między pokoleniami artystów w zakresie twórczych fundamentów: reżyserii i dramaturgii. Skrajne zubożenie teatru pod koniec lat dziewięćdziesiątych ubiegłego wieku i w pierwszej de- 
kadzie XXI, poczucie pełnej apatii społeczeństwa, niemożność samorealizacji - to wszystko doprowadziło do masowej ucieczki młodych reżyserów na Zachód. Z powodu braku bezpośredniego dialogu $\mathrm{z}$ widzem i hermetyzacji teatru nie można było oczekiwać postępów w nowej dramaturgii.

Zmiany zaczęły się około 2010 roku, jednak miały one charakter ledwie zauważalny i lokalny. W Czerkasach, Charkowie, Odessie, Chersoniu, Kijowie i Lwowie rodziło się nowe pokolenie dramaturgów, popularny stawał się teatr dokumentalny, widoczne były efekty prac teatru The Royal Court. Trwał coroczny festiwal Tydzień Aktualnej Sztuki Teatralnej („Тиждень актуальної п’єси”). Swoją działalność we Lwowie zapoczątkował festiwal „Dramat.UA” („Драма.UA”). Przybrały na sile procesy powrotu na Ukrainę, do ukraińskiej kultury i języka, do których wracali zarówno młodzi, jak i ci starsi reżyserowie i dramaturdzy. Dopiero dziś widać, iż wszystko to było niejako zapowiedzią Euromajdanu, wydarzeń, których nikt się nie spodziewał. Nowe pokolenie artystów teatralnych, które dorastało w ramach policyjno-totalitarnego reżimu, było nieodłączną częścią tego pokolenia, na którego barki spadnie ogromny ciężar i odpowiedzialność rewolucji godności z lat 20132014. Bardzo krótką genezę tego pokolenia można określić w następujący sposób: urodzeni i/lub wychowani w niepodległej Ukrainie.

III Ogólnoukraiński Festiwal Młodej Reżyserii, który odbywał się od 26 września do 4 października 2014 roku w Kijowie, potwierdził skrajnie pozytywne tendencje: młoda ukraińska reżyseria (Tetiana Trunowa, Anton Romanow, Maksym Hołenko, Oksana Prawosud i in.) wchodzi do ukraińskiego teatru razem z pokoleniem rówieśników, będących dramaturgami (Natalia Worożbyt, Pawło Arje, Wira Makowij, Kira Malinina, Jewhen Markowski, Roman Horbyk, Dmytro Łewycki, Saszko Brama i in.). O pokoleniu tych twórców można powiedzieć jedno: interesuje ich realne, nieupiększone, smutne, absurdalne, brudne, brutalne życie. Uciekając od jednoznacznych wniosków, od ideologicznych prostolinijnych tez, stawiają sobie za cel pokazanie współczesnych ludzi takimi, jakimi są. Artyści ci dogłębnie penetrują świadomość jednostki, która znalazła się w świecie pomiędzy — pomiędzy jednym a drugim systemem, pomiędzy prawdą a kłamstwem, naiwną wiarą a pełnym sceptycyzmem, pomiędzy stolicą a prowincją, między przymieraniem głodem w ojczyźnie a emigracją zarobkową na obczyźnie. W ich dziełach można odnaleźć bardzo osobiste historie: strach przed kataklizmami (Historia człowieka, któremu przydarzyła się historia [Історія людини, з якою сталася історія] K. Malininowej, Czerkaski Teatr Akademicki im. T. Szewczenki, 2014), burleskowy, jaskrawy, wyrazisty ukrainocentryzm (Wij.2.0 [Biŭ.2.0] N. Worożbyt, Kijowsko-Mohylańskie Centrum Teatralne „Пасіка", 2014), brutalną codzienność w świecie zapomnianym przez Boga (Lena [Лєна] D. Łewyckiego, Czerkaski Teatr Akademicki im. T. Szewczenki, 2014) czy kobiecy los na postsowieckiej prowincji (Нєвинасімі люді P. Gorbyka, Centrum Sztuk „Nowy Teatr Ukraiński”, Kijów 2014). Ich celem jest przeniknięcie do prywatnego, intymnego świata człowieka i jednocześnie obrona jego wymowy artystycznej — od szokującego naturalizmu do wesołej fantasmagorii. 
Wyznaczniki nowego ukraińskiego teatru i nowej dramaturgii są dziś w fazie kształtowania się, nie zawsze w sposób prosty i bezproblemowy odnajdując swoje miejsce w przestrzeni legitymizowanego, oficjalnego i profesjonalnego teatru. Właśnie konsolidacji tego nowego pokolenia i promocji jego działalności jest poświęcony wspomniany już festiwal Młodej Reżyserii. Zorganizowany i przeprowadzony $\mathrm{w}$ tym roku przez młodych przedstawicieli jeszcze jednego teatralnego cechu: teatroznawców (Iryna Czużynowa, Nadija Sokołenko, Wiktor Sobijański), udowodnił istnienie zawodowej solidarności i monolityczności, a także umiejętności przetrwania nowego pokolenia mimo wszystkich indywidualnych różnic, cechujących jego przedstawicieli.

Profesjonalny akademicki teatr ukraiński w całości, tak czy inaczej, pozostaje monolitem, pracuje i prowadzi dialog (a właściwie monolog — sic!) sam z sobą, przejawiając czy to strach, czy brak chęci otwartej dyskusji z widzem. W teatrze ukraińskim niestety wciąż istnieją schematy posttotalitarnego przystosowania się, których nie zdołano pokonać w całym okresie niezależności. Wciąż dominuje w nim chęć bycia uroczym, cnotliwym, pokojowo nastawionym, pięknym i dostępnym dla widza. Jest to teatr pozbawiony wyrazistych groteskowych form, satyry, brutalności, bólu, agresji, prawdy — zupełnie inaczej niż w życiu, które toczy się dookoła. Dlatego też największym wyzwaniem współczesnego ukraińskiego teatru jest przywrócenie zaufania widza, przełamanie hermetyzacji w kwestii komunikacji oraz rozpoczęcie otwartego dialogu ze społeczeństwem. Zadania, które przed nim stoją, są wyznaczane przez wieloaspektowe istnienie jednostki w posttotalitarnej, postkolonialnej, a teraz i w powojennej przestrzeni. W zależności od tego, jak bardzo uczciwie, szczerze i ciekawie będzie o tym mowa w teatrze, jak bardzo niezbędny stanie się on całemu społeczeństwu i każdemu widzowi z osobna, to w takim stopniu teatr ten będzie miał europejską przyszłość.

Tłumaczenie z języka ukraińskiego: Aniela Radecka 